\title{
Evaluation of QuEChERS Sample Preparation and Gas Chromatography Coupled to Mass Spectrometry for the Determination of Pesticide Residues in Grapes
}

\author{
Fernanda Volpatto, ${ }^{a}$ Arci D. Wastowski, ${ }^{a}$ Gabrieli Bernardi, ${ }^{b}$ Osmar D. Prestes, ${ }^{b}$ \\ Renato Zanella ${ }^{b}$ and Martha B. Adaime ${ }^{*, b}$
}

\author{
${ }^{a}$ Departamento de Ciências Agronômicas e Ambientais, Centro de Educação Superior Norte do Rio \\ Grande do Sul (CESNORS), Universidade Federal de Santa Maria, \\ 98400-000 Frederico Westphalen-RS, Brazil
}

${ }^{b}$ Laboratório de Análises de Resíduos de Pesticidas (LARP), Departamento de Química, Centro de Ciências Naturais e Exatas (CCNE), Universidade Federal de Santa Maria, 97105-900 Santa Maria-RS, Brazil

\begin{abstract}
An effective analytical method for pesticides multiresidue determination in grape samples was developed and validated. A modified quick, easy, cheap, effective, robust and safe (QuEChERS) method was used to extract the target compounds. Several sorbent materials were tested for the clean-up step using dispersive solid phase extraction (d-SPE) and Florisil ${ }^{\circledR}$ was selected. Samples extracts were evaporated before injection in the gas chromatography with mass spectrometry (GC-MS) system in order to improve detectability. Recoveries from blank samples spiked at 0.04 , 0.3 and $1.0 \mathrm{mg} \mathrm{kg}^{-1}$ ranged from 95 to $102 \%$ with relative standard deviation (RSD) from 1.3 to $19.7 \%$. Method limits of detection (LODm) and quantification (LOQm) ranged from 0.006 to 0.012 and 0.02 to $0.04 \mathrm{mg} \mathrm{kg}^{-1}$, respectively. The positive matrix effect caused an increase in the peak areas of all compounds and matrix matched calibration curve linearity (coefficient of determination, $\mathrm{r}^{2}$ ) was higher than 0.98 for all target analytes. The validated method was successfully applied for the determination of 19 pesticides in grape samples.
\end{abstract}

Keywords: QuEChERS, fruits, pesticides, GC-MS

\section{Introduction}

Agricultural products such as fruits, vegetables and cereals are the most analyzed matrices in routine laboratories, often presenting pesticide residues of different classes. ${ }^{1}$ Grape is widely cultivated and consumed worldwide, as well as its derivate products. Besides the pesticides use by grape growers, contamination may occur from indirect sources, such as other agricultural crops cultivated near to the vineyards. ${ }^{2}$ Thus, pesticide residues monitoring becomes essential to ensure food safety for consumers, especially in a situation where regulations are becoming increasingly restrictive in most countries. ${ }^{3}$

Because of the pesticide concentration are generally low and the analytes show different chemical properties, its determination requires a preliminary stage of sample preparation. Quick, easy, cheap, effective, robust and safe (QuEChERS) method was initially developed for fruits

*e-mail: martha@ufsm.br and vegetables by Anastassiades et al..$^{4}$ and it is based on an extraction step with acetonitrile followed by a partition step with salts and dispersive solid phase extraction (d-SPE) clean-up using small quantities of sorbents. Some modifications were proposed to the QuEChERS method, e.g., buffering, ${ }^{5,6}$ use of others extraction solvents, ${ }^{7}$ different sorbents as graphitized carbon black (GCB) ${ }^{8}$ octadecyl (C18), Florisil $^{\oplus}$ (magnesium silicate) and alumina, ${ }^{9}$ and the use of low temperature precipitation for fatty matrices. ${ }^{10}$ These modifications allowed the extraction of a large number of pesticides from different classes and matrices. Most part of the modifications was focused in the clean-up step and different sorbents have been used besides primary and secondary amine (PSA) and C18. ${ }^{11}$ Alumina or aluminum oxide $\left(\mathrm{Al}_{2} \mathrm{O}_{3}\right)$, commonly applied in chromatographic separation of lipophilic compounds, has been used as d-SPE sorbent for pesticides determination. ${ }^{12}$ Choi et al..$^{13}$ used GCB for the determination of pesticides in different matrices. Florisil ${ }^{\circledR}$, currently used for separation of non-polar or low polarity analytes, has been employed 
in sample preparation by QuEChERS and matrix solid phase dispersion (MSPD). ${ }^{14,15}$ Several publications have reported the determination of pesticides in grapes, using different extractions methods combined with liquid ${ }^{16,17}$ or gas chromatography. ${ }^{18-23}$ Melo et al..$^{16}$ use aminopropyl $\left(\mathrm{NH}_{2}\right)$ and C18 d-SPE sorbents combined with single wavelength high-performance liquid chromatography (HPLC) for multiclass determination of fungicides and herbicides in grapes. Limits of quantification (LOQ) values ranged from 43 to $86 \mu \mathrm{g} \mathrm{kg}^{-1}$ using a pre concentration factor of 2.5 . Banerjee et al..$^{20}$ optimized for multiresidue method with ethyl acetate extraction and d-SPE clean up using PSA. Gas chromatography with mass spectrometry (GC-MS) using single quadrupole were used for determination, achieving desired sensitivity and selectivity to 47 analytes in compliance with the maximum residue level (MRL) established by the European Commission (EU) ${ }^{24}$ The most common GC-MS techniques for the analysis of pesticides involves single quadrupole instrumentation with electron impact (EI) ionization. Ion trap detectors (ITD) are also used, presenting the advantage of higher sensitivity using the full-scan mode, when compared to single quadrupole. Savant et al. ${ }^{18}$ and González-Rodríguez et al.${ }^{19}$ successfully reported the use of GC-ITD for the determination of pesticides in grapes. GC-MS (single quadrupole or ITD) offers certain special benefits in terms of significantly less expensive instrumentation, low maintenance cost and easy operation..$^{20,25}$

A table grape cultivar known in Brazil as Isabel represents $50 \%$ of Brazilian grape production, being the basic raw material for the elaboration of table wine, grape juice and others derivatives. ${ }^{26,27}$ Results of the Brazilian pesticides monitoring programs from 2010 to 2012 for several crops showed that grape is one of the cultures with most irregularities regarding to non-authorized pesticides. ${ }^{28}$ Brazilian legislation establishes MRL for 49 pesticides in grape, ranging from 0.005 to $15 \mathrm{mg} \mathrm{kg}{ }^{-1} .{ }^{28}$ Bearing in mind these results, grow the concern over pesticides use and the need of methods able to achieve desirable limits for pesticides determination.

Due to the existence of few methods for the determination of pesticide residues in grapes and the occurrence of these compounds, this paper describes the optimization and validation of a modified QuEChERS method for determination of 19 pesticides in grape samples by GC-MS.

\section{Experimental}

\section{Chemicals, reagents and samples}

Toluene HPLC grade was acquired from Mallinckrodt Pharmaceuticals (Dublin, Ireland); acetonitrile HPLC grade and anhydrous magnesium sulfate $\left(\mathrm{MgSO}_{4}\right)$ from J. T. Baker (Tokyo, Japan). Acetic acid, sodium chloride and anhydrous sodium acetate were purchased from Vetec (Rio de Janeiro, Brazil). Florisil ${ }^{\circledR}$ was acquired from Anidrol (Diadema, Brazil); alumina and graphitized carbon black from Sigma-Aldrich (St. Louis, USA); Bondesil ${ }^{\circledR}$ PSA and Bondesi ${ }^{\oplus} \mathrm{C} 18$ were purchased from Agilent (Santa Clara, USA).

Blank grape samples from cultivar Isabel were obtained from organic controlled production (Frederico Westphalen, Brazil) and were processed and stored at $-18^{\circ} \mathrm{C}$ until analysis.

Pesticide analytical standards with purity between 94.0 and $99.5 \%$ were acquired from Dr. Ehrenstorfer GmbH (Augsburg, Germany). Quintozene ${ }^{29}$ and caffeine (both 99\%) were employed as surrogate standard (SS) and internal standard (IS), respectively. Standards were prepared in toluene in a concentration of $1000 \mathrm{mg} \mathrm{L}^{-1}$ and stored at $-18{ }^{\circ} \mathrm{C}$. From the individual stock solutions, a standard mixture containing $5 \mathrm{mg} \mathrm{L}^{-1}$ of each analyte was prepared in toluene and stored at $-18{ }^{\circ} \mathrm{C}$.

Instrumentation

The GC-MS system was a gas chromatograph 3900 GC coupled to an ion trap mass spectrometer detector Saturn 2100T and a CP 8400 autosampler; data was acquired using MS Workstation 6.9.2 software (Varian, Palo Alto, USA). Analytical balance AY220 from Shimadzu (Tokyo, Japan), sample concentrator Tecvap TE-0195 from Tecnal (Piracicaba, Brazil), centrifuges 206 BL from Fanem (Guarulhos, Brazil) and NT 810 from Nova Técnica (Piracicaba, Brazil) were used.

\section{GC-MS conditions of analysis}

Chromatographic separation was achieved on a Varian VF-5ms (Palo Alto, USA; 5\% fenil-95\% polydimethylsiloxane), capillary column $(30 \mathrm{~m} \times 0.25 \mathrm{~mm}$ i.d., $0.25 \mu \mathrm{m}$ of film thickness). Helium with a purity of 99.999\% (Linde, Munich, Germany) was used as the carrier gas. Aliquots of $2 \mu \mathrm{L}$ were injected in splitless mode with the injector temperature set at $300{ }^{\circ} \mathrm{C}$. The column oven temperature program was initially $80^{\circ} \mathrm{C}$ increasing to $200{ }^{\circ} \mathrm{C}$ at $25{ }^{\circ} \mathrm{C} \mathrm{min}{ }^{-1}$. Then, increasing to $230{ }^{\circ} \mathrm{C}$ at $3{ }^{\circ} \mathrm{C} \mathrm{min}{ }^{-1}$ and to $260{ }^{\circ} \mathrm{C}$ at $15{ }^{\circ} \mathrm{C} \mathrm{min}^{-1}$. Finally, temperature was raised to $280{ }^{\circ} \mathrm{C}$ at $30{ }^{\circ} \mathrm{C} \mathrm{min}^{-1}$ remaining for $6.5 \mathrm{~min}$. Total run time was $25 \mathrm{~min}$. The MS instrument was operated in the full-scan mode in a range between 50 and $500 \mathrm{~m} / \mathrm{z}$. At least three significant ions from each analyte were chosen for quantification and confirmation. Table 1 shows the selected compounds and their respective molecular formula, action 
mode, MRLs, retention time, and GC-MS quantification and confirmation ions. The manifold, trap and transfer line temperatures were set at 80,240 and $290{ }^{\circ} \mathrm{C}$, respectively. The emission current of the ionization filament was set at $40 \mu \AA$ and the amplitude voltage was $200 \mathrm{~V}$.

\section{Evaluation of sample preparation procedure}

The extraction process was evaluated to find the best method to extract the selected pesticides from grape samples. Thus, two versions of the QuEChERS method were evaluated: (i) QuEChERS original and (ii) QuEChERS acetate. ${ }^{4,5}$ The conditions used are described below.

\section{QuEChERS original extraction ${ }^{4}$}

Ten grams of homogenized grapes were transferred into a polypropylene $(\mathrm{PP})$ centrifuge tube $(50 \mathrm{~mL}) ; 20 \mu \mathrm{L}$ of surrogate standard $\left(100 \mathrm{mg} \mathrm{L}^{-1}\right)$ and $10 \mathrm{~mL}$ of acetonitrile were added. The tube was shaken vigorously in vortex (1 min) and after this $4 \mathrm{~g} \mathrm{MgSO}_{4}$ and $1 \mathrm{~g}$ sodium chloride were added. The mixture was immediately hand shaken for
$1 \mathrm{~min}$ and then was centrifuged at $2,420 \times \mathrm{g}$ for $20 \mathrm{~min}$. To the fortification assays a mix containing all the target analytes at a concentration of $0.5 \mathrm{mg} \mathrm{kg}^{-1}$ was added to the blank grape samples and let in contact with the sample for $1 \mathrm{~h}$ before extraction.

\section{QuEChERS acetate extraction ${ }^{5}$}

The same procedure as the QuEChERS original was performed changing only two conditions: use of acetonitrile with $1 \%(\mathrm{v} / \mathrm{v})$ acetic acid and sodium acetate instead of acetonitrile and sodium chloride, respectively.

\section{Clean-up options evaluated}

For the clean-up step, seven approaches of d-SPE cleanup were evaluated. For this purpose, $2 \mathrm{~mL}$ of extract was transferred to a PP centrifuge tube $(15 \mathrm{~mL})$ containing $300 \mathrm{mg}$ of $\mathrm{MgSO}_{4}$ and the sorbents according to Table 2. In all cases, tubes were hand shaken (1 min), centrifuged at $2,420 \times \mathrm{g}$ for $8 \mathrm{~min}$ and $1 \mathrm{~mL}$ of the supernatant after filtration in nylon filter $(0.2 \mu \mathrm{m})$ was evaporated under

Table 1. Selected compounds, molecular formula, action mode, Brazilian and European Union (EU) maximum residue level (MRL), retention time ( $\mathrm{t}_{\mathrm{R}}$ ) and monitored ions

\begin{tabular}{|c|c|c|c|c|c|c|}
\hline \multirow{2}{*}{ Compound } & \multirow{2}{*}{ Molecular formula } & \multirow{2}{*}{ Action mode } & \multicolumn{2}{|c|}{ MRL / (mg kg-1) } & \multirow{2}{*}{$\mathrm{t}_{\mathrm{R}} / \min$} & \multirow{2}{*}{$\begin{array}{l}\text { Monitored ion }{ }^{\mathrm{a}} / \\
(\mathrm{m} / \mathrm{z})\end{array}$} \\
\hline & & & Brazil & EU & & \\
\hline Chlorothalonil & $\mathrm{C}_{8} \mathrm{Cl}_{4} \mathrm{~N}_{2}$ & fungicide & 5 & 3 & 8.88 & $266,268,265$ \\
\hline Metalaxyl & $\mathrm{C}_{15} \mathrm{H}_{21} \mathrm{NO}_{4}$ & fungicide & 1 & 1 & 10.00 & $206,249,207$ \\
\hline Triadimefon & $\mathrm{C}_{14} \mathrm{H}_{16} \mathrm{ClN}_{3} \mathrm{O}_{2}$ & fungicide & 2 & 2 & 11.21 & $208,181,57,210$ \\
\hline Cyprodinil & $\mathrm{C}_{14} \mathrm{H}_{15} \mathrm{~N}_{3}$ & fungicide & NA & 5 & 11.98 & $224,210,225,226$ \\
\hline Procymidone & $\mathrm{C}_{13} \mathrm{H}_{11} \mathrm{Cl}_{2} \mathrm{NO}_{2}$ & fungicide & 5 & 0.01 & 12.59 & $96,283,285$ \\
\hline Endosulfan alpha & $\mathrm{C}_{9} \mathrm{H}_{6} \mathrm{Cl}_{6} \mathrm{O}_{3} \mathrm{~S}$ & insecticide & NA & 0.05 & 13.64 & $339,207,341$ \\
\hline Myclobutanil & $\mathrm{C}_{15} \mathrm{H}_{17} \mathrm{ClN}_{4}$ & fungicide & 0.5 & 1 & 14.51 & $179,181,180$ \\
\hline Buprofezin & $\mathrm{C}_{16} \mathrm{H}_{23} \mathrm{~N}_{3} \mathrm{OS}$ & insecticide & NA & 1 & 14.57 & $175,105,104$ \\
\hline Endosulfan beta & $\mathrm{C}_{9} \mathrm{H}_{6} \mathrm{Cl}_{6} \mathrm{O}_{3} \mathrm{~S}$ & insecticide & NA & 0.05 & 15.92 & $195,339,197$ \\
\hline Trifloxystrobin & $\mathrm{C}_{20} \mathrm{H}_{19} \mathrm{~F}_{3} \mathrm{~N}_{2} \mathrm{O}_{4}$ & fungicide & NA & 5 & 16.93 & $131,132,130,206$ \\
\hline Endosulfan sulfate & $\mathrm{C}_{16} \mathrm{H}_{23} \mathrm{~N}_{3} \mathrm{OS}$ & insecticide & NA & 0.05 & 17.16 & $387,272,389,385$ \\
\hline Tebuconazol & $\mathrm{C}_{16} \mathrm{H}_{22} \mathrm{ClN}_{3} \mathrm{O}$ & fungicide & 2 & 1 & 17.63 & $250,125,197$ \\
\hline Epoxiconazol & $\mathrm{C}_{17} \mathrm{H}_{13} \mathrm{ClFN}_{3} \mathrm{O}$ & fungicide & NA & 0.05 & 18.00 & $192,138,194$ \\
\hline Bifenthrin & $\mathrm{C}_{23} \mathrm{H}_{22} \mathrm{ClF}_{3} \mathrm{O}_{2}$ & insecticide & 0.1 & 0.2 & 18.38 & $181,166,165$ \\
\hline Fenpropathrin & $\mathrm{C}_{22} \mathrm{H}_{23} \mathrm{NO}_{3}$ & insecticide & NA & 0.01 & 18.71 & $181,265,182$ \\
\hline Tetradifon & $\mathrm{C}_{12} \mathrm{H}_{6} \mathrm{Cl}_{4} \mathrm{O}_{2} \mathrm{~S}$ & insecticide & NA & 0.01 & 19.00 & $356,159,358$ \\
\hline cis-Permethrin & $\mathrm{C}_{21} \mathrm{H}_{20} \mathrm{Cl}_{2} \mathrm{O}_{3}$ & insecticide & 0.05 & 0.05 & 20.56 & $183,184,165$ \\
\hline trans-Permethrin & $\mathrm{C}_{21} \mathrm{H}_{20} \mathrm{Cl}_{2} \mathrm{O}_{3}$ & insecticide & 0.05 & 0.05 & 20.74 & $183,184,165$ \\
\hline Etofenprox & $\mathrm{C}_{25} \mathrm{H}_{28} \mathrm{O}_{3}$ & insecticide & NA & 5 & 22.51 & $163,135,164$ \\
\hline Quintozene (SS) & $\mathrm{C}_{6} \mathrm{Cl}_{5} \mathrm{NO}_{2}$ & fungicide & - & - & 8.48 & $295,265,297,293$ \\
\hline Caffeine (IS) & $\mathrm{C}_{8} \mathrm{H}_{10} \mathrm{~N}_{4} \mathrm{O}_{2}$ & - & - & - & 9.40 & 194, 195, 109 \\
\hline
\end{tabular}

${ }^{a}$ The first ion of each line were used for quantification analysis. SS: Surrogate standard; IS: internal standard; NA: non-authorized. 
nitrogen stream, until $150 \mu \mathrm{L}$. The final volume was adjusted to $200 \mu \mathrm{L}$ with acetonitrile before injection.

Table 2. Clean-up conditions used to optimize the dispersive solid phase extraction (d-SPE) procedure for $2 \mathrm{~mL}$ of extracts

\begin{tabular}{lcccc}
\hline \multicolumn{5}{c}{ Sorbent amount / mg } \\
\hline PSA & C18 & ${\text { Florisi }{ }^{\odot}}^{\infty}$ & GCB & Alumina \\
\hline 50 & 0 & 0 & 20 & 0 \\
0 & 200 & 0 & 20 & 0 \\
50 & 0 & 0 & 0 & 0 \\
0 & 200 & 0 & 0 & 0 \\
50 & 200 & 0 & 0 & 0 \\
0 & 0 & 400 & 0 & 0 \\
0 & 0 & 0 & 0 & 200 \\
\hline
\end{tabular}

PSA: Primary and secondary amine; GCB: graphitized carbon black.

\section{Optimized method based on QuEChERS procedure}

Ten grams of homogenized grape sample were weighed in a $50 \mathrm{~mL} P P$ centrifuge tube and $100 \mu \mathrm{L}$ of the surrogate standard $\left(10 \mathrm{mg} \mathrm{L}^{-1}\right)$ were added in order to minimize the source of errors during samples preparation. Then, $10 \mathrm{~mL}$ of acetonitrile with $1 \%(\mathrm{v} / \mathrm{v})$ acetic acid was added and the tubes were shaken in vortex for $1 \mathrm{~min}$. Further, $4 \mathrm{~g} \mathrm{MgSO}_{4}$ and $1 \mathrm{~g}$ sodium acetate were added and the tubes were shaken immediately $(1 \mathrm{~min})$ in vortex. After, the tubes were centrifuged at $2,420 \times \mathrm{g}$ for $20 \mathrm{~min}$. Then, $2 \mathrm{~mL}$ of the supernatant were transferred to a $15 \mathrm{~mL}$ PP centrifuge tube containing $300 \mathrm{mg}$ of $\mathrm{MgSO}_{4}$ and $400 \mathrm{mg}$ of Florisi ${ }^{\oplus}$. The mixture was hand shaken for $1 \mathrm{~min}$ and centrifuged at $2,420 \times \mathrm{g}$ for $20 \mathrm{~min}$. The concentration step was conducted using $1 \mathrm{~mL}$ of the filtered supernatant $(0.2 \mu \mathrm{m})$ evaporating until $200 \mu \mathrm{L}$. After, $10 \mu \mathrm{L}$ of internal standard solution (caffeine, $10 \mathrm{mg} \mathrm{L}^{-1}$ ) were added before analysis by GC-MS.

\section{Method validation}

The proposed method was validated based on the parameters linearity, matrix effect, method limit of detection (LODm) and quantification (LOQm), and instrumental limit of detection (LODi) and quantification (LODi), accuracy (in terms of recovery) and precision (in terms of repeatability and intermediate precision, in accordance with the international regulation SANCO for pesticide residue analysis by chromatographic analysis). ${ }^{30}$ The linearity was evaluated through the coefficient of determination $\left(\mathrm{r}^{2}\right)$ of the analytical curve in the range of 0.02 to $1.0 \mathrm{mg} \mathrm{kg}^{-1}$. Matrix effect was calculated comparing the slope of curves prepared in acetonitrile and in the matrix blank extract. ${ }^{31}$ Accuracy was evaluated through recovery assays at three different concentration levels (0.04, 0.30 and $1.0 \mathrm{mg} \mathrm{kg}^{-1}$ ). Precision was evaluated regarding repeatability and intermediate precision by the relative standard deviation (RSD) of the recovery results. Three replicates of each concentration level were extracted and injected once in the GC-MS system. Instrumental LOD and LOQ were estimated using the signal-to-noise (S/N) ratio and the LOD was defined as the lowest concentration at which the analytical signal presented a $\mathrm{S} / \mathrm{N}$ ratio of 3:1. The method LOQ was established as the lowest spiked level concentration, which produced a $\mathrm{S} / \mathrm{N}$ ratio $\geq 10: 1$ with acceptable recovery (70-120\%) and precision (RSD $\leq 20 \%$ ) according to SANCO. ${ }^{30}$

\section{Results and Discussion}

\section{Chromatography determination}

The GC oven temperature program was optimized to separate all of the tested compounds with good peak shape, minimum matrix interferences, and increased sensitivity $(\mathrm{S} / \mathrm{N})$. For the optimization of the MS conditions, pesticide standards solutions at a concentration of $1000 \mu \mathrm{g} \mathrm{L} \mathrm{L}^{-1}$ were injected individually and mass spectra were acquired in the range between 100 and $500 \mathrm{~m} / z$. This evaluation aimed to identify the retention time and fragmentation of each analyte. Based on the acquired information, a mixture solution at $500 \mu \mathrm{g} \mathrm{L}{ }^{-1}$ containing all the compounds was analyzed by GC-MS in the selected ion monitoring (SIM) mode. In this study, $m / z$ values greater than 100 were chosen to avoid low molecular weight interferences from the matrix, except for procymidone that the most intense ion was $96 \mathrm{~m} / z$ (Table 1). Figure 1 presents the total ion chromatogram obtained by GC-MS (SIM) for the selected compounds. Separation of the compounds myclobutanil and buprofezin (peaks 7 and 8 , respectively) was not achieved but the compounds were still quantified separately due to the ability of mass spectrometer in recognize different $\mathrm{m} / \mathrm{z}$ fragments.

\section{Extraction and clean-up optimization}

Sample preparation is a critical part of multiresidue methods due to the widely different physicochemical properties, such as polarity, water solubility and volatility of pesticides. ${ }^{32}$ Grapes contain significant amounts of naturally matrix components, ${ }^{33}$ which are also co-extracted with the target pesticides. ${ }^{21}$ In this work, two sample preparation strategies based on original and acetate QuEChERS methods with seven different clean-up 


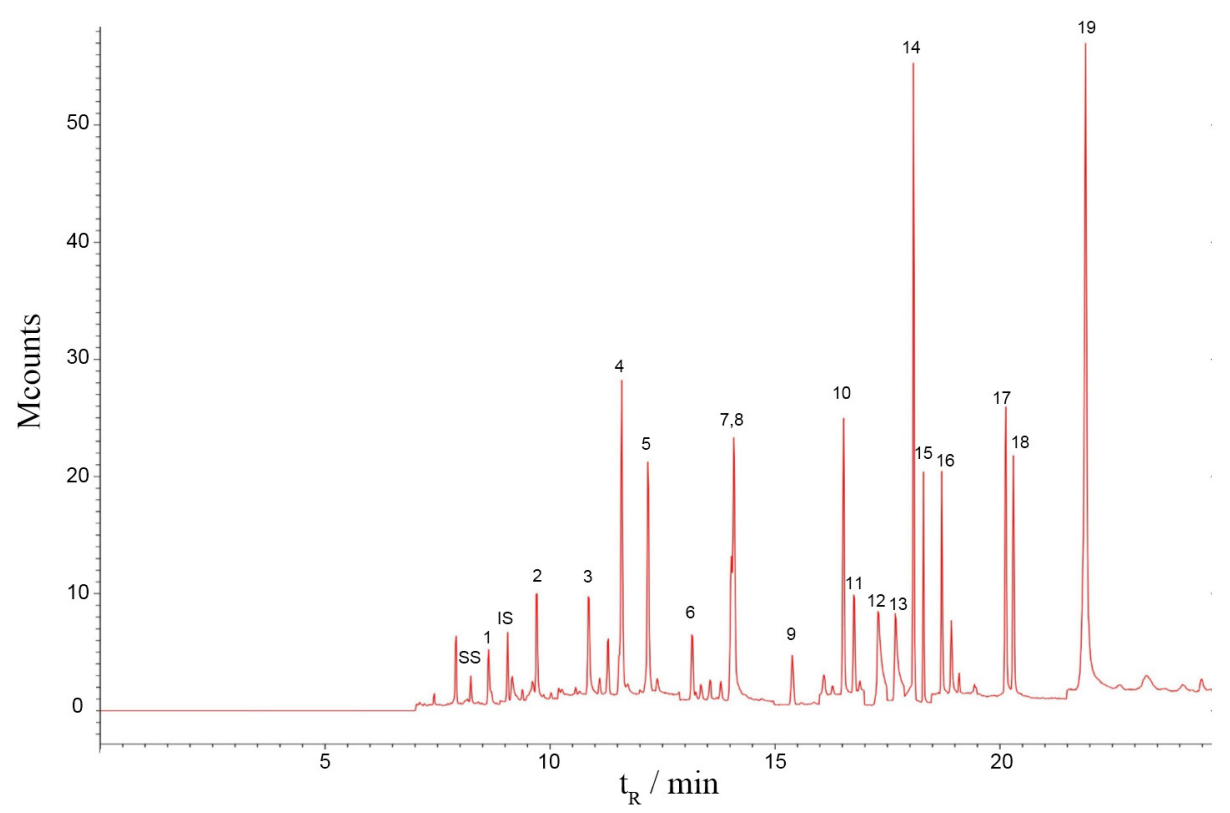

Figure 1. Gas chromatography with mass spectrometry (GC-MS) in the selected ion monitoring (SIM) total ion chromatogram of a blank matrix matched standard solution at $1.0 \mathrm{mg} \mathrm{kg}^{-1}$ containing all the selected pesticides: (1) chlorotalonil, (2) metalaxil, (3) triadimefom, (4) ciprodinil, (5) procimidone, (6) endosulfan alpha, (7) miclobutanil, (8) buprofenzin, (9) endosulfan beta, (10) trifloxystrobin, (11) endosulfan sulfate, (12) tebuconazol, (13) epoxiconazol, (14) bifenthrin, (15) fenpropatrin, (16) tetradifon, (17) cis-permethrin, (18) trans-permethrin, (19) etofemprox, (SS) quintozene and (IS) caffeine.

approaches were evaluated based on recoveries of the compounds. These procedures were selected considering that they were previously used for the extraction of a wide range of pesticides from fruits and vegetables. ${ }^{34-36}$ Figure 2 shows that the QuEChERS procedure using the acetate buffered version at $\mathrm{pH} 4.8$ presented higher and more consistent recoveries for most compounds, including the $\mathrm{pH}$ dependent pesticides cyprodinil, myclobutanil and tebuconazol. ${ }^{5}$

Natural pigments does not interfere directly in the chromatographic analysis of pesticides, but can remained in the injector liner and the chromatographic column, shortening the useful life of this devices. ${ }^{37}$ In the clean-up step, it was found that GCB provided an adequate clean-up, resulting in almost colorless extracts. In contrast to GCB, C18 and alumina provided the most colorful extracts, as can be seen in Figure 3.

However, besides the GCB efficiency in color removal, this sorbent caused poor recoveries with both, original and acetate, extractions. This is justified by the fact that GCB has a tendency to adsorb organic compounds including pesticides, especially those with planar structure, such as chlorothalonil and cyprodinil. ${ }^{38}$ When PSA or C18 were used alone, color removal was not as efficient as using GCB. However, the number of compounds with adequate recovery was higher, especially when QuEChERS acetate method was applied (Figure 4). Using a mixture of PSA and $\mathrm{C} 18$, the number of analytes with recovery between 70

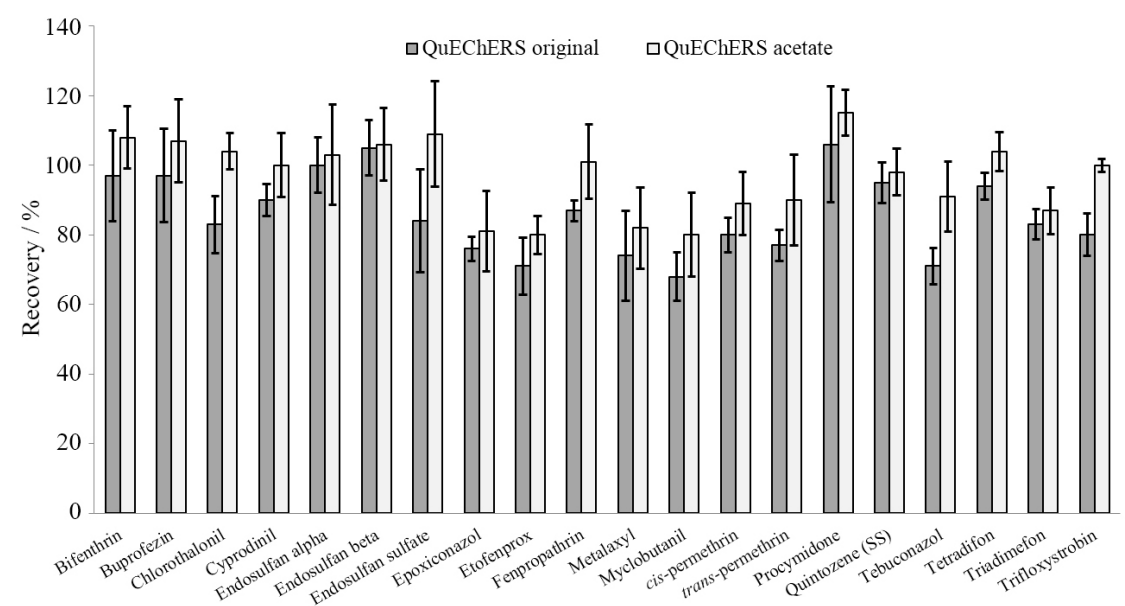

Figure 2. Recoveries results obtained with the application of both QuEChERS procedures (original and acetate) to blank grape samples spiked at $0.5 \mathrm{mg} \mathrm{kg}{ }^{-1}$ $(\mathrm{n}=3)$ with the mixture containing all the target analytes and the surrogate standard (SS) at a concentration of $0.2 \mathrm{mg} \mathrm{kg}^{-1}$. 
and $120 \%$ was lower than using only PSA, but higher than using only C18. In this case, it is possible to conclude that C18 is retaining some of the compounds, like buprofezin, endosulfan alpha, endosulfan beta, tebuconazol and trifloxystrobin, resulting in low recoveries. Miao et al. ${ }^{15}$ used only Florisi ${ }^{\circledR}(200 \mathrm{mg})$ as clean-up sorbent applying d-SPE in lotus seed QuEChERS extract. In the present work, a good color removal, similar to PSA, was obtained using $400 \mathrm{mg}$ of Florisi ${ }^{\circledR}$ and more compounds presented adequate recovery (Figure 4). Based on these results and on the fact that Florisil $^{\circledR}$ is an inexpensive sorbent, Florisil ${ }^{\circledR}$ was selected and the amount of sorbent was optimized. For this purpose, 200, 300 and $400 \mathrm{mg}$ of Florisil ${ }^{\circledR}$ were tested. As expected, $400 \mathrm{mg}$ presented a less color extract and the number of compounds with adequate recovery did not decrease (19 compounds). Therefore, $400 \mathrm{mg}$ of Florisil ${ }^{\circledR}$ was chosen for method validation.

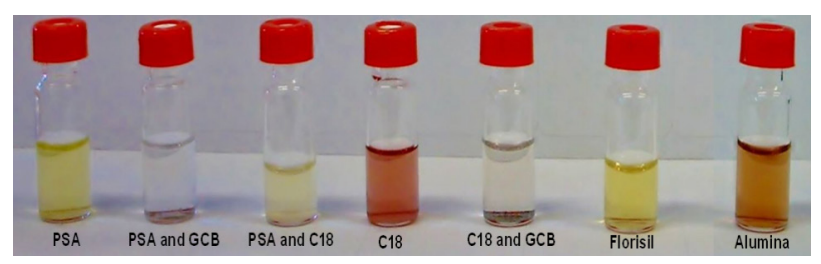

Figure 3. Final extract obtained after the application of dispersive solid phase extraction (d-SPE) clean-up with different sorbents. PSA: Primary and secondary amine; GCB: graphitized carbon black.

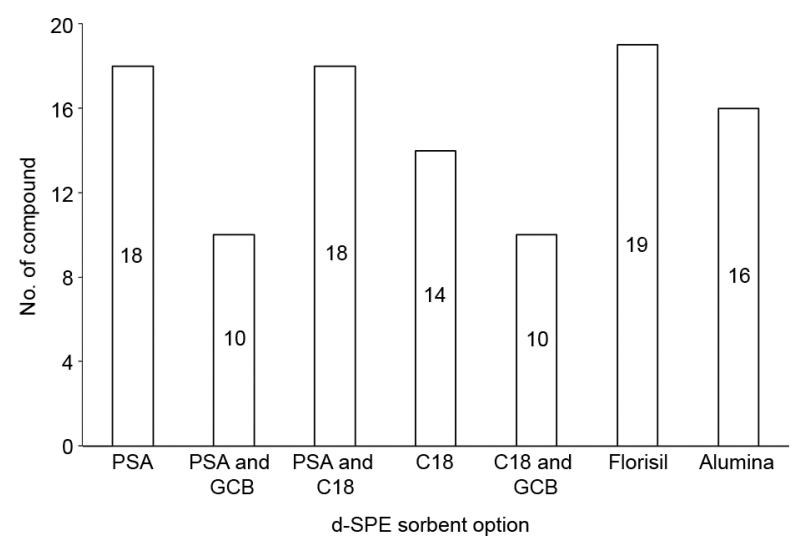

Figure 4. Number of compounds with recoveries between 70 and $120 \%$ obtained with the application of QuEChERS acetate procedure and different clean-up options applied in blank grape samples spiked at $0.5 \mathrm{mg} \mathrm{kg}^{-1}(\mathrm{n}=3)$. PSA: Primary and secondary amine; GCB: graphitized carbon black; d-SPE: dispersive solid phase extraction.

\section{Method validation}

Validation parameters were evaluated and the selectivity was confirmed since no interferences were observed in the blank extract compared with a spiked grape sample. Analytical curves presented good linearity with $\mathrm{r}^{2}>0.99$ for all the studied compounds, except for myclobutanil and tebuconazol that presented $\mathrm{r}^{2} \geq 0.98$. Results for method
LOD and LOQ, linear range, linearity $\left(\mathrm{r}^{2}\right)$, matrix effect, accuracy, evaluated through recovery tests and precision in terms of repeatability and intermediate precision, are shown in Table 3. Recovery values for spiked levels ranged between 70.1 and $120.0 \%$, except for epoxiconazol (108-121\%) and trifloxystrobin (119-125\%). Good precision was observed for all the substances with RSD in terms of repeatability between 3.9 and $19.7 \%$. Intermediate precision was also evaluated and the recovery values ranged from 71 to $123 \%$ with RSD between 0.4 and $19.1 \%$. Method LOQs values ranged between 0.02 and $0.04 \mathrm{mg} \mathrm{kg}^{-1}$ that are below to the MRL established by Brazilian legislation. ${ }^{28}$ Matrix effect was also evaluated and an increase in the chromatographic signal and sensitivity for all analytes was observed (Table 3 ). These results confirm the need of perform quantifications using a matrix matched calibration curve. Cunha et al..$^{39}$ evaluated the matrix effect for different pesticides in grapes, wine and must, observing that the chromatographic signal obtained by GC-MS increase for most studied pesticides when in presence of matrix. Grapes have a high sugar content ${ }^{27}$ besides others co-extractives that may remain solubilized in the organic extracts being responsible for increase gas chromatographic signal and sensitivity ${ }^{40}$

The validation parameters achieved with the proposed method are comparable with those already published. Limits of detection and quantification (0.006- $\left.0.02 \mathrm{mg} \mathrm{kg}^{-1}\right)$ shown to be lower than those found by Alves et al. ${ }^{21}$ (3.75-9.47 $\left.\mathrm{mg} \mathrm{kg}^{-1}\right)$ and You et al. ${ }^{17}\left(0.5-5.0 \mathrm{mg} \mathrm{kg}{ }^{-1}\right)$, even using a concentration technique as solid phase extraction (SPE) and ultrasound-assisted dispersive liquid-liquid microextraction based on solidification of floating organic droplet (UA-DLLME-SFO), respectively. Banerjee et al. ${ }^{20}$ used ethyl acetate extraction followed by d-SEP clean-up with PSA and reported LOQ values from 0.01 to $0.02 \mathrm{mg} \mathrm{kg}^{-1}$, being very similar to those reported in this work, which proves that Florisi ${ }^{\oplus}$ can be used as an alternative sorbent to PSA.

\section{Application to real samples}

The validated method was applied for the analysis of 10 real samples collected from a local market in Frederico Westphalen, RS, Brazil. Residues of cyprodinil were found in two samples at 0.021 and $0.030 \mathrm{mg} \mathrm{kg}^{-1}$. This compound is non-authorized for grape culture according to Brazilian legislations. ${ }^{28}$ However, the positive results for this compound in grape samples are in accordance with a report published by Brazilian Health Surveillance Agency (ANVISA), were this fungicide was also found in grapes from a Brazilian monitoring program. ${ }^{41}$ Besides, Cesnik et al..$^{42}$ also found cyprodinil residues between 
Table 3. Limit of detection (LOD) and quantification (LOQ); linear range; coefficient of determination $\left(\mathrm{r}^{2}\right)$; matrix effect (ME); and recovery and precision results for repeatability and intermediate precision assay; obtained with spiked blank samples at three different levels

\begin{tabular}{|c|c|c|c|c|c|c|c|c|c|c|c|c|c|}
\hline \multirow{3}{*}{ Pesticide } & \multirow{3}{*}{$\begin{array}{l}\mathrm{LODi}^{\mathrm{a}} / \\
\left(\mathrm{mg} \mathrm{L}^{-1}\right)\end{array}$} & \multirow{3}{*}{$\begin{array}{l}\mathrm{LOQi}^{\mathrm{a}} / \\
\left(\mathrm{mg} \mathrm{L}^{-1}\right)\end{array}$} & \multirow{3}{*}{$\begin{array}{l}\mathrm{LODm}^{\mathrm{b}} / \\
\left(\mathrm{mg} \mathrm{kg}^{-1}\right)\end{array}$} & \multirow{3}{*}{$\begin{array}{l}\mathrm{LOQm}^{\mathrm{b}} / \\
\left(\mathrm{mg} \mathrm{kg}^{-1}\right)\end{array}$} & \multirow{3}{*}{$\begin{array}{c}\text { Linear } \\
\text { range / } \\
\left(\mathrm{mg} \mathrm{kg}^{-1}\right)\end{array}$} & \multirow{3}{*}{$\mathrm{r}^{2}$} & \multirow{3}{*}{$\begin{array}{c}\mathrm{ME} / \\
\%\end{array}$} & \multirow{2}{*}{\multicolumn{3}{|c|}{$\begin{array}{l}\text { Repeatability } \\
\text { Recovery /\% }\end{array}$}} & \multirow{2}{*}{\multicolumn{3}{|c|}{$\begin{array}{c}\text { Intermediate precision } \\
\text { Recovery } / \%\end{array}$}} \\
\hline & & & & & & & & & & & & & \\
\hline & & & & & & & & $\begin{array}{c}0.04 \\
\mathrm{mg} \mathrm{kg}^{-1}\end{array}$ & $\begin{array}{c}0.3 \\
\mathrm{mg} \mathrm{kg}^{-1}\end{array}$ & $\begin{array}{c}1.0 \\
\mathrm{mg} \mathrm{kg}^{-1}\end{array}$ & $\begin{array}{c}0.04 \\
\mathrm{mg} \mathrm{kg}^{-1}\end{array}$ & $\begin{array}{c}0.3 \\
\mathrm{mg} \mathrm{kg}^{-1}\end{array}$ & $\begin{array}{c}1.0 \\
\mathrm{mg} \mathrm{kg}^{-1}\end{array}$ \\
\hline Bifenthrin & 0.03 & 0.1 & 0.006 & 0.02 & $0.02-1.0$ & 0.99 & 283 & $105(7.1)$ & $86(5.2)$ & $97(9.8)$ & $117(7.7)$ & $101(19.5)$ & $107(11.8)$ \\
\hline Buprofenzin & 0.06 & 0.2 & 0.012 & 0.04 & $0.04-1.0$ & 0.99 & 242 & $107(8.4)$ & $95(3.6)$ & $103(9.3)$ & $107(1.5)$ & $104(8.8)$ & $108(10.6)$ \\
\hline Chlorothalonil & 0.03 & 0.1 & 0.006 & 0.02 & $0.02-1.0$ & 0.98 & 317 & $87(7.7)$ & $75(16.8)$ & $91(14.6)$ & $83(13.7)$ & 71(12.01) & $79(0.4)$ \\
\hline Cyprodinil & 0.03 & 0.1 & 0.006 & 0.02 & $0.02-1.0$ & 0.99 & 106 & $106(6.8)$ & $97(7.6)$ & $107(08)$ & $102(5.4)$ & $103(6.4)$ & $106(4.9)$ \\
\hline Endosulfan alpha & 0.06 & 0.2 & 0.012 & 0.04 & $0.04-1.0$ & 0.98 & 237 & $102(12.9)$ & $88(11.4)$ & $107(18)$ & $106(4.4)$ & $104(13.2)$ & $108(11.2)$ \\
\hline Endosulfan beta & 0.06 & 0.2 & 0.012 & 0.04 & $0.04-1.0$ & 0.99 & 178 & $105(10.4)$ & $98(3.6)$ & $102(10.8)$ & $111(4.1)$ & $98(14.3)$ & $105(1.4)$ \\
\hline Endosulfan sulfate & 0.03 & 0.1 & 0.006 & 0.02 & $0.02-1.0$ & 0.99 & 154 & $103(9.2)$ & $77(1.6)$ & $97(13.7)$ & $100(4.8)$ & $88(19.6)$ & $97(9.2)$ \\
\hline Epoxiconazol & 0.06 & 0.2 & 0.012 & 0.04 & $0.04-1.0$ & 0.98 & 836 & $108(18.1)$ & $117(7.9)$ & $121(17.4)$ & $111(19.1)$ & $118(8.3)$ & $110(14)$ \\
\hline Etofenproxy & 0.03 & 0.1 & 0.006 & 0.02 & $0.02-1.0$ & 0.99 & 625 & $100(5.7)$ & $86(7.5)$ & $99(13.1)$ & 101(14.7) & $86(5.8)$ & $96(10.4)$ \\
\hline Fenpropathrin & 0.03 & 0.1 & 0.006 & 0.02 & $0.02-1.0$ & 0.99 & 241 & $107(1.8)$ & $86(3.4)$ & $98(11.8)$ & $107(10.8)$ & 101(16.2) & $107(12.4)$ \\
\hline Metalaxyl & 0.03 & 0.1 & 0.006 & 0.02 & $0.02-1.0$ & 0.98 & 341 & $98(17.6)$ & $86(7.1)$ & $105(14.4)$ & $105(18.7)$ & $77(11.1)$ & $92(8.5)$ \\
\hline Myclobutanil & 0.06 & 0.2 & 0.012 & 0.04 & $0.04-1.0$ & 0.98 & 936 & $89(19.7)$ & $102(6.9)$ & $111(6.3)$ & $72(19)$ & $89(13.83)$ & $118(6.4)$ \\
\hline cis-permethrin & 0.03 & 0.1 & 0.006 & 0.02 & $0.02-1.0$ & 0.99 & 351 & $104(7.7)$ & $89(5.4)$ & $99(10.9)$ & $108(4.2)$ & $101(7.5)$ & $103(9.1)$ \\
\hline trans-permethrin & 0.03 & 0.1 & 0.006 & 0.02 & $0.02-1.0$ & 0.99 & 405 & $99(9.7)$ & $90(3.6)$ & $97(12.4)$ & $114(5.1)$ & $103(15)$ & $105(9.6)$ \\
\hline Procymidone & 0.06 & 0.2 & 0.012 & 0.04 & $0.04-1.0$ & 0.99 & 175 & $107(8.2)$ & $88(1.3)$ & $102(9.7)$ & $119(08)$ & $102(11.2)$ & $104(9.2)$ \\
\hline Tebuconazol & 0.06 & 0.2 & 0.012 & 0.04 & $0.04-1.0$ & 0.98 & 1228 & $119(7.2)$ & $115(4.1)$ & $90(14.1)$ & $123(15.7)$ & $117(14)$ & $87(19)$ \\
\hline Tetradifon & 0.03 & 0.1 & 0.006 & 0.02 & $0.02-1.0$ & 0.99 & 266 & $97(18.7)$ & $83(10.3)$ & $105(12.7)$ & $106(31.2)$ & $88(15.2)$ & $107(14.3)$ \\
\hline Triadimefon & 0.06 & 0.2 & 0.012 & 0.04 & $0.04-1.0$ & 0.98 & 765 & $112(5.1)$ & $82(14.6)$ & $98(9.1)$ & $105(12.8)$ & $84(18.3)$ & $92(9.6)$ \\
\hline Trifloxystrobin & 0.06 & 0.2 & 0.012 & 0.04 & $0.04-1.0$ & 0.99 & 321 & $119(8.6)$ & $125(3.9)$ & $122(7.2)$ & $98(8.8)$ & $123(18.1)$ & $120(13.8)$ \\
\hline
\end{tabular}

aODi: instrumental limit of detection and LOQi: quantification;; ${ }^{\mathrm{L}} \mathrm{LODm}$ : method limit of detection and LOQm: quantification; ${ }^{\circ}$ values in brackets are relative standard deviation $(\mathrm{n}=3)$.

0.03 and $0.40 \mathrm{mg} \mathrm{kg}$, which confirm the use of this compound during grape cultivation.

\section{Conclusions}

The buffered QuEChERS extraction method using acetonitrile with acetic acid and sodium acetate proved to be effective for the extraction of pesticide residues from different chemical groups in grape samples. The conditions of clean-up were optimized, which revealed that the use of Florisil ${ }^{\circledR}$ was adequate to obtain extracts in conditions to perform the analysis by GC-MS. The sample preparation procedure established in this work has the advantage of being simple and easy to perform, minimizing errors. In addition, it is cheap and environmentally friend due to the use of few organic solvents. Florisil ${ }^{\circledR}$ is an inexpensive sorbent when compared to the frequently used sorbents.

The combination of the sample preparation step with GC-MS provided a sensitive and selective method for the simultaneous determination of 19 pesticides in grape samples and can be applied in routine analysis. Good recovery and precision as well as low method LOQ were reached, indicating the reliability of the data obtained with the proposed method. The results obtained with the method application indicate a potential risk to the consumer, since cyprodinil is non-authorized for use in grapes.

\section{Acknowledgments}

The authors are grateful to the Brazilian agencies CNPq, CAPES, FAPERGS and FINEP for the financial support and fellowship.

\section{References}

1. Lozano, A.; Kiedrowska, B.; Scholten, J.; Kroon, M.; Kok, A.; Fernández-Alba, A. R.; Food Chem. 2016, 192, 668.

2. Hildebrandt, A.; Guillamón, M.; Lacorte, S.; Tauler, R.; Barceló, D.; Water Res. 2008, 42, 3315.

3. Li, J.; Zhang, H. F.; Shi, Y. P.; Food Chem. 2011, 127, 784.

4. Anastassiades, M.; Lehotay, S. J.; Stajbaher, D.; Schenck, F. J.; J. AOAC Int. 2003, 86, 412.

5. Lehotay, S. J.; Maštovská, K.; Lightfield, A. R.; J. AOAC Int. 2005, 88,615 .

6. Andrascikovaand, M.; Hrouzkova, S.; Anal. Methods 2013, 5, 1374. 
7. Sahoo, S. K. R.; Battu, S.; Singh, B.; Am. J. Anal. Chem. 2011, $2,26$.

8. Paz, M.; Correia-Sá, L.; Becker, H.; Longhinotti, E.; Domingues, V. F.; Delerue-Matos, C.; Food Control 2015, 54, 374.

9. Cerqueira, M. B. R.; Caldas, S. S.; Primel, E. G.; J. Chromatogr. A 2014, 1336, 10.

10. Sobahnzadeh, E.; Bakar, N. K. A.; Abas, M. R. B.; Nemati, K.; Environ. Monit. Assess. 2012, 184, 5821.

11. Arias, J. L. O.; Rombaldi, C.; Caldas, S. S.; Primel, E. G.; J. Chromatogr. A 2014, 1360, 66.

12. Koesukwiwat. U.; Sanguankaew, K.; Leepipatpiboon, N.; Anal. Chim. Acta 2008, 626, 10.

13. Choi, S.; Kim, S.; Shin J. Y.; Kim, M.; Kim, J. H.; Food Chem. 2015, 173, 1236.

14. Capriotti, A. L.; Cavaliere, C.; Laganà, A.; Piovesana, S.; Samperi, R.; TrAC, Trends Anal. Chem. 2013, 43, 53.

15. Miao, Q.; Kong, W.; Yang, S.; Yang, M.; Chemosphere 2013, 91, 955.

16. Melo, L. F. C.; Collins, C. H.; Jardim, I C. C. S. F.; J. Chromatogr. A 2004, 1032, 51.

17. You, X.; Jiang, W.; Liu, F.; Liu, C.; Food Anal. Methods 2013, $6,1515$.

18. Savant, R. H.; Banerjee, K.; Utture, S. C.; Patil, S. H.; Dasgupta. S.; Ghaste, M. S.; Adsule, P. G.; J. Agric. Food Chem. 2010, $58,1447$.

19. González-Rodríguez, R. M.; Cancho-Grande, B.; SimalGándara, J.; J. Chromatogr. A 2009, 1216, 6033.

20. Banerjee, K.; Mujawar, S.; Utture, S. C.; Dasgupta S.; Adsule P. G.; Food Chem. 2013, 138, 600.

21. Alves, A. A. R.; Rodrigues, A. S.; Barros, E. B. P.; Uekane, T. M.; Bizzo, H. R.; Rezende, C. M.; Food Anal. Methods 2014, 7, 1834 .

22. Hanot, V.; Joly, L.; Bonnechère, A.; van Loco, J.; Food Anal. Methods 2015, 8, 524.

23. Dehouck, P.; Grimalta, S.; Dabrio, M.; Cordeiro, F.; Fiamegos, Y.; Robouch, P.; Fernández-Alba, A. R.; Callea, B.; J. Chromatogr. A 2015, 1395, 143.

24. European Commission - European Food Safety Authority; EU Legislation on MRLs, Regulation EC 396/2005 and amendments; European Commission: 2015. Available at http:// ec.europa.eu/food/plant/pesticides/legislation/max_residue_ levels_en.htm, accessed in January 2016.

25. Stan, H.-J. In Comprehensive Analytical Chemistry. Chromatographic-Mass Spectrometric Food Analysis for Trace Determination of Pesticide Residues, Volume XLIII; Barceló, D., ed.; Elsevier: Oxford, 2005, ch. 6.
26. Nixdorf, S. L.; Hermosín-Gutiérrez, I.; Anal. Chim. Acta 2010, 659, 208.

27. Rizzon, L. A.; Miele, A.; Meneguzzo, J.; Cienc. Tecnol. Aliment. (Campinas, Braz.) 2000, 20, 115.

28. Agencia Nacional de Vigilância Sanitária (ANVISA); Limite Máximo de Resíduos (LMR); ANVISA: Brasília, DF, Brasil, 2008.

29. Orso, D.; Martins, M. L.; Donato, F. F.; Rizzetti, T. M.; Kemmerich, M.; Adaime, M. B.; Zanella, R.; J. Braz. Chem. Soc. 2014, 25, 1355.

30. European Commission - Health \& Consumer Protection Directorate-General; Guidance Document on Analytical Quality Control and Validation Procedures for Pesticide Residues Analysis in Food and Feed SANCO/12571. European Commission: 2013.

31. Ferrer, C.; Lozano, A.; Aguera, A.; Giron, A. J.; Fernandez-Alba, A. R.; J. Chromatogr. A 2011, 1218, 7634.

32. Presta, M. A.; Bruyneel, B.; Zanella, R.; Kool, J.; Kraabbe, J. G.; Lingeman, H.; Chromatographia 2009, 69, 167.

33. Walorczyk, S.; Drozdzynski, D.; Gnusowski, B.; Talanta 2011, $85,1856$.

34. Carneiro, R. P.; Oliveira, F. A. S.; Madureira, F. D.; Silva, G.; Souza, W. R.; Lopes, R. P.; Food Control 2013, 33, 413.

35. Golge, O.; Kabak, B.; J. Food Compos. Anal. 2015, 41, 86.

36. Rizzetti, T. M.; Kemmerich, M.; Martins, M. L.; Prestes, O. D.; Adaime, M. B.; Zanella, R.; Food Chem. 2016, 196, 25.

37. Sousa, F. A.; Costa, A. I. L. G.; Queiroz, M. E. L. R.; Teófilo, R. F.; Pinho, G. P.; Neves, A. A.; Chromatographia 2013, 76, 67.

38. Cabrera, L. C.; Martins, M. L.; Primel, E. G.; Prestes, O. D.; Adaime, M. B.; Zanella, R.; Scientia Chromatographica 2012, $4,227$.

39. Cunha, S. C.; Fernandes, J. O.; Alves, A.; Oliveira, M. B. P. P.; J. Chromatogr. A 2009, 1216, 119.

40. Sousa, F. A.; Costa, A. I. L. G.; Queiroz, M. E. L. R.; Teófilo, R. F.; Neves, A. A.; Pinho, G. P.; Food Chem. 2012, 135, 179.

41. Agencia Nacional de Vigilância Sanitária (ANVISA); Programa de Análise de Resíduos de Agrotóxicos em Alimentos (PARA): Relatório de Atividades de 2009; ANVISA: Brasília, DF, Brasil, 2009.

42. Česnik, H. B.; Gregorčič, A.; Čuš, F.; Food Addit. Contam. 2008, 25, 438 .

Submitted: October 27, 2015

Published online: February 1, 2016

FAPERGS/CAPES has sponsored the publication of this article. 